\section{PENGARUH MEKANISME \\ CORPORATE GOVERNANCE \\ TERHADAP LUAS PENGUNGKAPAN \\ MODAL INTELEKTUAL: STUDI \\ PADA PERUSAHAAN SEKTOR PERBANKAN}

\author{
Afifah Novita Hardiani, Ihyaul Ulum, Siti Zubaidah \\ Program Studi Akuntansi Fakultas Ekonomi dan Bisnis \\ Universitas Muhammadiyah Malang \\ Jl. Raya Tlogomas No.246 Malang \\ Email: afifahnovita28@gmail.com
}

JRAK

\title{
Abstract
}

\begin{abstract}
The aim of this research is to examine the affect of corporate governance mechanism on disclosure of intellectual capital on the banking sector companies. 27 companies were taken as samples on this research. The objective of this research is to prove the affect of corporate governance mechanism on disclosure of intellectual capital on the banking sector companies. The analytical methods used in this research are Partial Least Square (PLS) and test directly (direct effect). Results indicated that the variable of corporate governance was positively affect the disclosure of intellectual capital on the banking sector companies which means all information in companies were disclosed.
\end{abstract}

Keywords: mekanisme corporate governance, intellectual capital disclosure

\section{PENDAHULUAN}

Pengungkapan intellectual capital dalam suatu laporan merupakan pelaporan sukarela. Pengungkapan intellectual capital dimaksudkan untuk memenuhi kebutuhan informasi bagi pengguna seluruh pemangku kepentingan perusahaan. Dalam pelaporan informasi yang berkaitan dengan modal intelektual di Indonesia belum ada standar yang menetapkan item-item apa saja yang termasuk dalam intangible asset baik mandatory disclosure maupun voluntary disclosure.

Menurut Abeysekera (2008) pengungkapan IC menjadi penting bagi investor karena menjelaskan berbagai macam aktivitas, terutama perusahaan di lingkungan ekonomi yang intens berkompetisi secara global. Pengungkapan informasi IC (ICD) dalam laporan tahunan entitas merupakan informasi penting bagi investor mengenai nilai pasar yang ada di entitas tersebut. Pembuatan laporan pengungkapan IC merupakan hal yang sangat penting untuk dilakukan perusahaan karena menurut Sutedi (2011) kewajiban perusahaan untuk melakukan pengungkapan (disclousure) secara akurat, tepat waktu, dan transparans terhadap semua informasi kinerja perusahaan, kepemilikan, dan stakeholders. Hal tersebut merupakan salah satu konsep dari corporate governance.

Analisis isi (content analysis) sering digunakan sebagai metode dalam mengidentifikasi pengungkapan modal intelektual (ICD). ICD adalah jumlah pengungkapan informasi tentang IC yang disajikan dalam laporan tahunan perusahaan. Salah satu pengukuran yang digunakan adalah dengan menggunakan ICD-In (Intellectual Capital Disclosure) di kembangkan oleh Ulum et al. (2014).

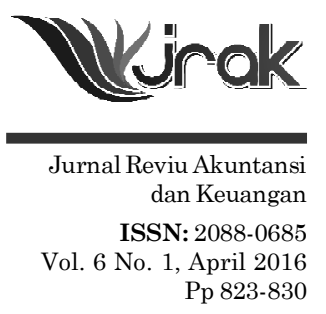


Pengaruh

Mekanisme

Corporate

Governance...

824

Penyelidikan tentang pengaruh corporate governance terhadap intellectual capital disclosure juga dilakukan oleh Li et al. (2008). Li et al. (2008) melakukan penelitian untuk menguji pengaruh faktor tata kelola perusahaan terhadap IC disclosure dan terdiri dari subkategorinya, menggunakan variasi pengukuran pengungkapan. Penerapan corporate governance yang baik diharapkan mampu meningkatkan harga saham perusahaan yang akhirnya dapat meningkatkan nilai perusahaan.

Cerbioni dan Parbonetti (2007) menyatakan bahwa secara keseluruhan mekanisme corporate governance yang terdiri dari keindependensian komisaris independen, ukuran dewan, CEO duality,dan struktur dewan secara kuantitas mempunyai pengaruh yang positif terhadap pengungkapan intellectual capital (IC), sedangkan secara kualitas hanya keindependensian komisaris independen yang berpengaruh terhadap pengungkapan Intelektual capital (IC). Li et al. (2008) berhipotesis bahwa ada hubungan yang signifikan antara IC disclosure dalam laporan tahunan dan komposisi dewan, dualitas peran, konsentrasi kepemilikan, ukuran komite audit serta frekuensi rapat komite audit, pengendalian untuk usia listing, ukuran perusahaan dan profitabilitas. Penelitian ini menggunakan 100 perusahaan terdaftar di UK.

Berdasarkan hasil penelitian sebelumnya, peneliti tertarik untuk mengkombinasi dan memodifikasi hasil penelitian dari Cerbioni dan Parbonetti (2007) dan (Li et al., 2008) dengan menggunakan perusahan sektor perbankan yang berada di Indonesia pada tahun 2011-2015.

\section{PENGEMBANGAN HIPOTESIS}

\section{Teori Pensinyalan (Signaling Theory)}

Signaling theory pada dasarnya concern dengan penurunan asimetri informasi di antara dua pihak (Spence, 2002). Teori pensinyalan berkaitan dengan bagaimana mengatasi masalah yang timbul dari asimetri informasi dalam seting sosial. Hal ini menunjukkan bahwa asimetri informasi dapat dikurangi jika pihak yang memiliki informasi dapat mengirim sinyal kepada pihak terkait. Teori penyisalan menyatakan bahwa perusahaan berkualitas tinggi akan cenderung memberikan sinyal keunggulan mereka kepada pasar. Pada suatu sisi, sinyal akan membuat investor dan pemangku kepentingan yang lain menaikkan nilai perusahaan, dan kemudian membuat keputusan yang lebih menguntungkan bagi perusahaan (Whiting dan Miller, 2008).

\section{Intellectual Capital Disclosure}

Sejak tahun 2000an, para akademisi dan praktisi mulai fokus pada persoalan pengungkapan IC (intellectual capital disclosure - ICD) perusahaan di dalam laporan tahunannya (lihat misalnya: (Guthrie et al., 1999; Guthrie dan Petty, 2000; Guthrie. J et al., 2004). Definisi ICD adalah jumlah pengungkapan banyak diperdebatkan diantara para ahli dalam berbagai literatur (Ulum, 2015a).

\section{Corporate Governance (CG)}

Corporate Governance dapat didefinisikan sebagai suatu proses dan struktur yang digunakan oleh organ perusahaan (Pemegang Saham, Pemilik Modal, Komisaris/ Dewan Pengawas dan Direksi) untuk meningkatkan keberhasilan usaha dan akuntabilitas perusahaan guna mewujudkan nilai pemegang saham dalam jangka panjang dengan tetap memperhatikan kepentingan stakeholder lainnya, berlandaskan peraturan perundang-undangan dan nilai-nilai etika (Sutedi, 2011). 
Pengaruh mekanisme corporate governance terhadap luas pengungkapan modal intelektual di perusahaan sektor perbankan.

Menurut Sutedi (2011) kerangka kerja corporate governance harus memastikan diungkapkannya informasi materiil perusahaan yang akurat dan tepat waktu, antara lain meliputi situasi keuangan, kinerja perusahaan, pemegang saham, dan manjemen perusahaan serta faktor risiko yang mungkin timbul. Informasi material yang perlu diungkapkan meliputi antara lain hasil keuangan dan usaha perusahaan, pemegang saham utama, anggota board of director's dan esekutif, risiko yang mungkin dihadapi, struktur dan kebijakan perusahaan serta target yang ingin dicapai. Di dalam mekanisme corporate governance peneliti memilih tiga proxy berdasarkan penelitian terdahulu yaitu ukuran dewan komisaris, ukuran komite audit, dan frekuensi pertemuan komite audit.

Coller dan Gregory (1999) menyatakan bahwa semakin besar jumlah anggota dewan komisaris maka akan semakin mudah untuk mengendalikan manajemen dan monitoring yang dilakukan juga akan semakin efektif sehingga akan meminimalisasi agency cost.

Albitar (2015) menyimpulkan bahwa ukuran perusahaan, leverage, umur perusahaan, profitabilitas, likuiditas, ukuran dewan komisaris dan ukuran komite audit berpengaruh terhadap pengungkapan sukarela dan direktur independen dan struktur kepemilikan tidak berpengaruh terhadap pengungkapan sukarela.

Li et al. (2008) membuktikan bahwa ada hubungan positif antara frekuensi pertemuan komite audit dan tingkat pengungkapan IC. Taliyang dan Jusop (2011) menyimpulkan bahwa frekuensi pertemuan audit berpengaruh terhadap pengungkapan modal intelektual dan komposisi dewan komisaris, peran dualitas, dan ukuran komite audit tidak berpengaruh terhadap pengungkapan modal intelektual.

$\mathrm{H}_{1}$ : Semakin baik mekanisme corporate governance suatu perusahaan maka semakin banyak luas pengungkapan modal intelektualnya di perusahaan sektor perbankan.

\section{METODE}

Populasi dalam penelitian ini adalah perusahaan sektor perbankan. Perusahaan perbankan dipilih sebagai populasi karena lebih intensif pengetahuan dan teknologi komunikasi, sehingga dalam menjalankan aktivitasnya lebih banyak menggunakan IC dibandingkan dengan aset fisik pada perusahaan manufaktur (Firer dan Mitchell Williams, 2003). Teknik penentuan sample menggunakan purposive sampling adalah merupakan metode penetapan sampel dengan berdasarkan pada kriteria-kriteria tertentu (Ulum dan Juanda, 2016). Adapun kriteria yang digunakan untuk pemilihan sampel sebagai berikut:

1. Perusahaan perbankan yang memiliki unit usaha syariah (UUS) dan bank umum syariah (BUS).

2. Mempublikasikan laporan tahunan dari tahun 2011-2015

3. Data dapat di akses

Variabel independen dalam penelitian ini adalah mekanisme corporate governance. Variabel independen dalam penelitian ini adalah proxy dari corporate governance yaitu ukuran dewan komisaris, ukuran komite audit, dan frekuensi pertemuan komite audit. Dewan komisaris adalah dewan yang bertugas melakukan pengawasan dan memberi nasihat kepada direktur atau direksi. Di Indonesia, dewan komisaris ditunjukoleh RUPS dan di dalam UU No. 40 tahun 2007 tentang Perseroan Terbatas yang dijabarkan mengenai fungsi wewenang dan tanggung jawab dari dewan komisaris. Untuk mengukur ukuran dewan komisaris yaitu dengan menggunakan jumlah anggota dewan komisaris suatu perusahaan. 
Pengaruh

Mekanisme

Corporate

Governance...

826
Sementara Komite audit adalah komite yang dibentuk oleh dewan komisaris dalam rangka membantu melaksanakan tugas dan fungsinya. Menurut peraturan BAPEPAM Kep 29/PM/2004 tentang peraturan nomor IX.1.5 menyatakan bahwa komite audit terdiri dari sekurang-kurangnya satu orang komisaris independen dan 2 (dua) anggota lainnya berasal dari luar perusahaan. Untuk mengukur ukuran komite audit yaitu dengan jumlah anggota pada komite audit.

Berdasarkan keputusan Ketua Bapepam Nomor Kep-24/PM/2004 dalam peraturan Nomor IX.1.5 menjelaskan bahwa komite audit mengadakan pertemuan sekurang-kurangnya sama dengan ketentuan minimal rapat dewan komisaris yang ditetapkan dalam anggaran dasar perusahaan. Untuk mengukur frekuensi pertemuan komite audit dengan cara menghitung jumlah rapat komite audit yang diadakan pada periode laporan tahunan.

Variabel dependen dalam penelitian ini adalah luas pengungkapan modal intelektual yang diperoleh dengan mengacu pada framework 36 item atau bisa disebut juga ICD-In (Intellectual Capital Disclosure Indonesia) yang dikembangkan oleh (Ulum, 2015). Dalam skema ini, IC dikelompokkan dalam 3 kategori yang terdiri dari 36 item - 3 kategori dan 36 item yang dimaksud adalah sebagai berikut: kategori Human capital 8 item; structural capital 15 item; dan relational capital 13 item; 15 diantaranya adalah item modifikasi, diberi kode (M). Pengukuran Intellectual capital disclosure (ICD) ini dapat dicari dengan angka index (ICDindex).

Teknik analisis data yang dilakukan pada penelitian ini yaitu menggunakan content analysis dengan menggunakan variabel independen mekanisme corporate governance dan variabel dependen luas pengungkapan modal intelektual yang menggunakan program PLS.

1. Menggunakan metode content analysis berdasarkan kerangka konsep IC (Purnomosidhi, 2006). Content analysis menggunakan 4 cara sistem kode numerik (four-away numerical coding system) untuk mengidentifikasi luas dan tingkat pengungkapan Intellectual Capital dalam annual report perbankan. Kode numerik (four away numerical coding system) yang digunakan adalah:

$0 \quad$ : item tidak diungkapkan dalam laporan tahunan.

1 : item diungkapkan dalam bentuk narasi

2 : item diungkapkan dalam bentuk numerik

3 : item diungkapkan dengan nilai moneter

2. Analisis data dilakukan dengan metode Partial Least Square(PLS). PLS adalah metode penyelesaian structural equation modelling (SEM) yang dalam hal ini (sesuai tujuan penelitian) lebih tepat dibandingkan dengan teknik-teknik SEM lainnya. Dalam PLS Path Modeling terdapat dua model yaitu outer model dan inner model.

\section{HASIL DAN PEMBAHASAN}

\section{Content Analysis}

Berdasarkan teknik analisis data yang dilakukan pada penelitian ini menggunakan metode content analysis dengan menggunakan 4 cara sistem kode numerik (four-away numerical coding system) untuk mengidentifikasi luas dan tingkat pengungkapan intellectual capital dalam annual report perbankan.

Berdasarkan Gambar 4.1 menunjukkan bahwa, peningkatan yang terjadi pada item yang diungkapkan dalam bentuk narasi (skor=1) terjadi pada tahun 2014 yaitu $51 \%$ menjadi $54 \%$ pada tahun 2015 . Penurunan yang terjadi pada item yang tidak diungkapkan (skor=0) dalam laporan tahunan terjadi pada tahun 2011 yaitu $37 \%$ menjadi $33 \%$ pada tahun 2012, pada tahun $201333 \%$ menjadi $29 \%$, dan pada tahun $201429 \%$ menjadi $27 \%$. 
Tahapan pertama yaitu penilaian outer model atau measurement model, untuk menilai outer model dapat melihat dari koefisien regresi dan signifikansi dari koefisien regresi tersebut.

Keterangan: *** $\tilde{\mathrm{n}}<0.01,{ }^{* *} \tilde{\mathrm{n}}<0.05 ; * \tilde{\mathrm{n}}<0.10, \mathrm{R}^{2}=0,38$

Gambar 4.2 menggambarkan output WarpPLS 3.0 secara keseluruhan. Jalur CG-ICD menunjukkan nilai koefisien 0.57 dengan nilai signifikan pada $\tilde{\mathrm{n}}<0.01$ (***) pengaruh langsung (direct effect) dalam model penelitian, serta setiap kontrol tahun untuk variabel independen (ICD). Setiap tambahan satu variabel independen, maka $\mathrm{R}^{2}$ pasti meningkat, hal tersebut tidak melihat apakah variabel tersebut berpengaruh secara signifikan terhadap variabel dependen. Untuk melihat hasil yang lebih detail dapat dilihat pada Tabel 4.3 berikut

Berdasarkan hasil output 'model fit indices and $P$ value' diketahui bahwa nilai $\mathrm{APC}=0.192, \mathrm{P}<0.001, \mathrm{ARS}=0.384, \mathrm{P}<0.001, \mathrm{AVIF}=1.006$, Good if $<5$. Ketentuan WarpPLS menyatakan bahwa nilai ñ untuk APC dan ARS harus lebih kecil dari 0,05 (signifikan). Selain itu, AVIF sebagai indikator multikolinearitas harus lebih kecil dari 5. Mengacu pada ketentuan tersebut, dapat disimpulkan bahwa ketiga indikator fit telah memenuhi kriteria. Hal ini menunjukkan bahwa model yang diajukan didukung oleh data.

Berdasarkan output WarpPLS untuk sebagaimana disajikan di tabel 4.4 ICD yang di proxykan dengan ukuran dewan komisaris menunjukkan nilai koefisien 0.466 dengan $\tilde{\mathrm{n}}<0,001$ dan VIF 1.213 , ICD yang di proxykan dengan ukuran komite audit menunjukkan nilai koefisien 0.499 dengan $\tilde{\mathrm{n}}<0,001$ dan VIF 1.269 dan ICD yang di proxykan dengan frekuensi pertemuan komite audit menunjukkan nilai koefisien 0.394 dengan $\tilde{\mathrm{n}}<0,001$ dan VIF 1.103. Jadi indikator mekanisme corporate governance dengan ukuran dewan komisaris, ukuran komite audit, dan frekuensi pertemuan komite audit berpengaruh positif terhadap luas pengungkapan modal intelektual dengan nilai $\tilde{\mathrm{n}}<0.05$ (signifikan) dan nilai VIF $<3.3$.

Tahap selanjutnya melakukan penilaian inner model atau structural model. Penilaian inner model dapat dilihat pada Tabel 4.4 menyajikan data $R$-squared, $Q$-squared dan Full collinearity VIF. Hasil R-squared, Q-squared and Full collinearity VIF dapat dilihat pada tabel 4.5.

Hasil output WarpPLS untuk sebagaimana di sajikan di tabel 4.3 nilai $\tilde{n}$ untuk APC dan ARS lebih kecil dari 0.05 (signifikan) dan AVIF sebagai indikator multikolinearitas lebih kecil dari 5. Mengacu pada ketentuan WarpPLS, dapat disimpulkan bahwa model direct effect adalah fit. Gambar output direct effect berdasarkan hasil pengolahan menggunakan WarpPLS dapat dilihat pada gambar 4.3:

Keterangan: *** $\tilde{\mathrm{n}}<0.01 ; * * \tilde{\mathrm{n}}<0.05 ; * \tilde{\mathrm{n}}<0.10$

Pada gambar 4.3 hubungan langsung (direct effect) hasil WarpPLS menunjukan jalur CG-ICD menunjukan nilai koefisien 0.57 dengan $\tilde{n}<.01(* * *)$ signifikan. Dengan demikian hipotesis diterima. Hal tersebut menunjukkan bahwa CG berpengaruh terhadap ICD dengan besarnya kemampuan CG untuk menjelaskan variabel ICD adalah $38 \%$.

Berdasarkan penelitian yang telah dilakukan terhadap hipotesis dalam penelitian, hasilnya menunjukkan bahwa mekanisme corporate governance berpengaruh signifikan terhadap intellectual capital disclosure. Hasil ini menunjukkan hipotesis yang diajukan diterima. Hasil hipotesis tersebut menjelaskan bahwa mekanisme corporate governance yang baik akan memberikan pengungkapan secara luas terhadap pihak eksternal (stakeholder) yang membutuhkan informasi mengenai perusahaan guna kepentingannya. Hal tersebut cenderung memberikan sinyal positif terhadap pasar dengan di buktikan pada teori pensinyalan terutama fokus pada penyampaian informasi positif sebagai upaya untuk memperoleh atribut organisasi yang positif pula (Connelly et al., 2011). 


\section{Pengaruh \\ Mekanisme \\ Corporate \\ Governance..}

828
Sebuah sinyal dapat menjadi suatu tindakan yang dapat diamati, atau struktur yang diamati, yang digunakan untuk menunjukkan karakteristik tersembunyi (atau kualitas) dari signaler tersebut. Teori tersebut juga menyebutkan bahwa perusahaan berkualitas tinggi akan cenderung memberikan sinyal keunggulan mereka kepada pasar. Pada satu sisi, sinyal akan membuat investor dan pemangku kepentingan yang lain menaikkan nilai perusahaan, dan kemudian membuat keputusan yang lebih menguntungkan bagi perusahaan.

Hasil dari ketiga proxy semua menunjukkan hubungan yang signifikan antara mekanisme corporate governance dengan intellectual capital disclosure. Cerbioni dan Parbonetti (2007) yang menyimpulkan bahwa ukuran dewan komisaris berbanding terbalik dengan kualitas pengawasan sehingga pengungkapan menjadi tidak mencukupi. Semakin banyak jumlah anggota dewan komisaris maka akan menimbulkan beberapa masalah diantaranya adalah adanya masalah komunikasi dan koordinasi, karena kurangnya koordinasi bisa jadi membuat kemampuan dewan komisaris untuk mengawasi pihak manajemen menjadi berkurang, sehingga timbul masalah agency (Cerbioni dan Parbonetti, 2007).

Hasil penelitian pada ukuran komite audit menurut Taliyang dan Jusop (2011) menyimpulkan bahwa frekuensi pertemuan audit berpengaruh terhadap pengungkapan modal intelektual dan komposisi dewan komisaris, peran dualitas, dan ukuran komite audit tidak berpengaruh terhadap pengungkapan modal intelektual.

Hasil pada frekuensi pertemuan komite audit berpengaruh dan signifikan. Li et al. (2008) meyatakan bahwa rapat komite audit merupakan salah satu aktivitas penting dalam mengawasi perilaku manajemen dengan memperhatikan intellectual capital disclosure untuk mengurangi asimetri informasi. Koordinasi dalam rapat komite audit membahas mengenai strategi dan evaluasi pelaksanaan tugas seperti pengawasan laporan keuangan, pengendalian internal, serta pengawasan terhadap tata kelola perusahaan yang baik.

\section{Simpulan}

Penelitian ini bertujuan untuk menguji pengaruh mekanisme corporate governance terhadap luas pengungkapan modal intelektual pada perusahaan sektor perbankan. Dari hasil penelitian yang dilakukan pada 27 perusahaan sampel selama periode 2011 sampai dengan 2015 dengan metode analisis yang digunakan adalah content analysis. Untuk menganalisis hubungan antar variabel tersebut, penelitian ini menggunakan dua metode content analysis dan Partial Least Square (PLS). Dapat disimpulkan bahwa semakin baik mekanisme corporate governance suatu perusahaan maka semakin banyak jumlah luas pengungkapan modal intelektualnya. Hasil dari pengujian tersebut dijelaskan bahwa mekanisme corporate governance berpengaruh terhadap Intellectual Capital Disclosure artinya tidak adanya informasi yang tidak diungkapkan dalam perusahaan.

\section{Keterbatasan penelitian}

Pada penelitian ini masih ada keterbatasan yang menghambat selama penelitian dilakukan. Diharapkan dengan adanya keterbatasan ini peneliti selanjutnya mampu mengatasi agar hasil penelitian yang dilakukan lebih maksimal sesuai dengan yang diharapkan peneliti.

1. Keterbatasan ini terletak pada saat melakukan pengujian dengan metode content analysis dengan Framework 36 item. Penilaian yang subyektif membuat peneliti pada saat mengidentifikasi item IC dari laporan tahunan terkadang sulit menentukan apakah item tersebut diungkapkan atau tidak di dalam laporan tahunan. Subjektivitas dapat disebabkan oleh karakteristik data atau pihak peneliti sehingga memungkinkan untuk memanipulasi data.

2. Pada indikator variabel independent terlalu sedikit, peneliti hanya menggunakan tiga indikator dari variabel independent, yaitu ukuran dewan komisaris, ukuran komite audit, dan frekuensi pertemuan komite audit. 
3. Sampel yang digunakan dalam perusahaan yang akan diteliti terlalu sedikit karena ada berbagai faktor yang tidak sesuai dengan kriteria yang telah ditentukan.

\section{Saran}

Dari keterbatasan peneliti tersebut ada saran yang diajukan yaitu:

1. Sebaiknya dalam mengukur pengungkapan modal intelektual dengan menggunakan content analysis dalam pemberian bobot penilaian pengungkapan modal intelektual di lakukan oleh beberapa orang karena dalam penilaian ini subyektif. Subjektivitas dapat disebabkan oleh karakteristik data atau pihak peneliti sehingga memungkinkan untuk memanipulasi data. Hal tersebut di harapkan dalam pemberian bobot penilaian lebih maksimal.

2. Adanya penambahan indikator pada variabel independent tidak hanya tiga indikator yang digunakan, alangkah baiknya lebih dari tiga indikator.

3. Menggunakan objek lainnya agar mendapatkan sampel yang maksimal untuk diteliti

\section{DAFTAR PUSTAKA}

Abeysekera, I. 2008. "Intellectual capital disclosure trends: Singapore and Sri Lanka". Journal of Intellectual Capital, Vol. 9 (4), No., hlm: 723-737.

Albitar, K. 2015. "Firm Characteristics, Governance Attributes and Corporate Voluntary Disclosure: A Study of Jordanian Listed Companies". International Business Research, Vol. 8 (3), No., hlm.

Cerbioni, F., dan A. Parbonetti. 2007. "Exploring the Effects of Corporate Governance on Intellectual Capital Disclosure: An Analysis of European Biotechnology Companies". European Accounting Review, Vol. 16 (4), No., hlm: 791826.

Coller, P., dan A. Gregory. 1999. "Audit committee activity and agency cost". Journal of Accounting and Public Policy, Vol. 18, No. 4-5, hlm: 311-332.

Connelly, B. L., S. T. Certo, R. D. Ireland, dan C. R. Reutzel. 2011. "Signaling theory: A review and assessment". Journal of Management, Vol. 37, No. 1, hlm: 39-67.

Firer, S., dan S. Mitchell Williams. 2003. "Intellectual capital and traditional measures of corporate performance". Journal of Intellectual Capital, Vol. 4, No. 3, hlm: 348-360.

Guthrie, J., dan R. Petty. 2000. "Intellectual capital: Australian annual reporting practices”. Journal of Intellectual Capital, Vol. 1, No. 3, hlm: 241-251.

Guthrie, J., R. Petty, F. Ferrier, dan R. Wells. Year. "There is no accounting for intellectual capital in Australia: a review of annual reporting practices and the internal measurement of intangibles". Artikel dipresentasikan pada $O E C D$ Symposium on Measuring and Reporting of Intellectual Capital, Amsterdam, di.

Guthrie.J, R. Petty, dan K. Yongvanich. 2004. "Using content analysis as a research method to inquire into intellectual capital reporting". Journal of Intellectual Capital, Vol. 5 (2), No., hlm: 282-293.

Li, J., R. Pike, dan R. Haniffa. 2008. "Intellectual capital disclosure and corporate governance structure in UK firms". Accounting and Business Research, Vol. 38, No. 2, hlm: 137-159.

Purnomosidhi, B. 2006. "Praktik Pengungkapan Modal Intelektual pada Perusahaan Publik BEJ”. Jurnal Riset Akuntansi Indonesia, Vol. 9 (1), No., hlm: 1-20. 
Pengaruh

Mekanisme

Corporate

Governance...

830
Spence, M. 2002. "Signaling in retrospect and the informational structure of markets". The American Economic Review, Vol. 92, No. 3, hlm: 434-459.

Sutedi, A. 2011. Good Corporate Governance. Jakarta: Sinar Grafika.

Taliyang, S. M., dan M. Jusop. 2011. "Intellectual Capital Disclosure and Corporate Governance Structure: Evidence in Malaysia". International Journal of Business and Management, Vol. 6 (12), No., hlm: 109-117.

Ulum, I. 2015. "Peran Pengungkapan Modal Intelektual Dan Profitabilitas Dalam Hubungan Antara Kinerja Modal Intelektual Dengan Kapitalisasi Pasar “, Disertasi Tidak Dipublikasikan, Program Doktor Ilmu Ekonomi

Universitas Diponegoro, Semarang. . 2015a. Intellectual Capital: Model Pengukuran, Framework Pengungkapan, dan Kinerja Organisasi: Malang: UMM Press.

Ulum, I., I. Ghozali, dan A. Purwanto. 2014. "Konstruksi Model Pengukuran Kinerja dan Kerangka Kerja Pengungkapan Modal Intelektual”. JAMAL (Jurnal Akuntansi Multiparadigma), Vol. 5, No. 3, hlm: 380-392.

Ulum, I., dan A. Juanda. 2016. Metodologi Penelitian Akuntansi: Klinik Skripsi 2. Malang: Aditya Media Publishing.

Whiting, R. H., dan J. C. Miller. 2008. "Voluntary disclosure of intellectual capital in New Zealand annual reports and the "hidden value"'. Journal of Human Resource Costing \& Accounting, Vol. 12, No. 1, hlm: 26-50. 